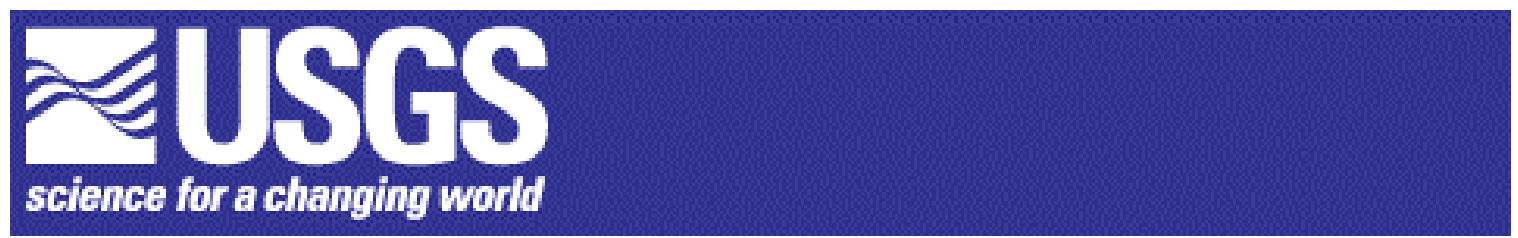

\title{
Lithology of gravel deposits of the Front Range Urban Corridor, Colorado: Data and multivariate statistical analysis
}

By David A. Lindsey

Open-File Report 01-299

2001

This report is preliminary and has not been reviewed for conformity with U.S. Geological Survey editorial standards or with the North American Stratigraphic Code. Any use of trade, firm, or product names is for descriptive purposes only and does not imply endorsement by the U.S. Government.

U.S. DEPARTMENT OF THE INTERIOR

U.S. GEOLOGICAL SURVEY

${ }^{1}$ Lakewood, Colorado 


\section{Table of Contents}

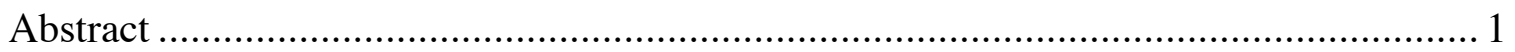

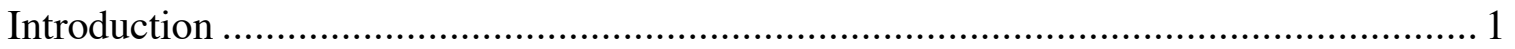

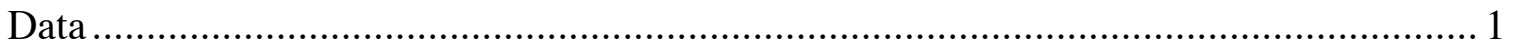

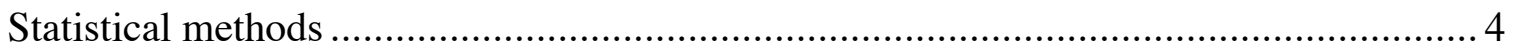

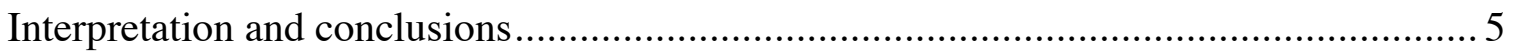

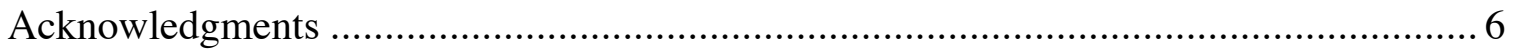

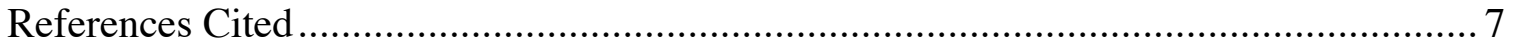


Figure

Figure 1.--Map showing gravel pits and localities for pebble count data in the Front Range Urban Corridor north of Denver, Colo.

\section{Tables}

Table 1.--Excel file of pebble counts, with sample locations, data sources, and classification of localities by terrace, gravel deposits of the Front Range Urban Corridor, Colo.

Table 2.--Excel file of pebble count data prepared for statistical analysis, including combined rock types, row geometric means, and centered log-ratio data, gravel deposits of the Front Range Urban Corridor, Colo.

Table 3.--Centered log-ratio correlation matrix, pebble count data, gravel deposits of the Front Range Urban Corridor, Colo.

Table 4.--Eigenvalues, log-contrast principal components analysis of pebble count data, gravel deposits of the Front Range Urban Corridor, Colo.

Table 5.--Unrotated log-contrast principal components matrix, pebble count data, gravel deposits of the Front Range Urban Corridor, Colo.

Table 6.--Communalities, log-contrast principal components analysis of pebble count data, gravel deposits of the Front Range Urban Corridor, Colo.

Table 7.--Orthogonal factor loadings, Varimax rotation, log-contrast principal components analysis, gravel deposits of the Front Range Urban Corridor, Colo.

Table 8.--Factor interpretation, log-contrast principal components analysis, gravel deposits of the Front Range Urban Corridor, Colo. 


\title{
Lithology of gravel deposits of the Front Range Urban Corridor, Colorado: Data and multivariate statistical analysis
}

\author{
By David A. Lindsey
}

\begin{abstract}
Pebble count data from Quaternary gravel deposits north of Denver, Colo., were analyzed by multivariate statistical methods to identify lithologic factors that might affect aggregate quality. The pebble count data used in this analysis were taken from the map by Colton and Fitch (1974) and are supplemented by data reported by the Front Range Infrastructure Resources Project. This report provides data tables and results of the statistical analysis.

The multivariate statistical analysis used here consists of log-contrast principal components analysis (method of Reyment and Savazzi, 1999) followed by rotation of principal components and factor interpretation.

Three lithologic factors that might affect aggregate quality were identified: 1) granite and gneiss versus pegmatite, 2) quartz + quartzite versus total volcanic rocks, and 3) total sedimentary rocks (mainly sandstone) versus granite. Factor 1 (grain size of igneous and metamorphic rocks) may represent destruction during weathering and transport or varying proportions of rocks in source areas. Factor 2 (resistant source rocks) represents the dispersion shadow of metaquartzite detritus, perhaps enhanced by resistance of quartz and quartzite during weathering and transport. Factor 3 (proximity to sandstone source) represents dilution of gravel by soft sedimentary rocks (mainly sandstone), which are exposed mainly in hogbacks near the mountain front. Factor 1 probably does not affect aggregate quality. Factor 2 would be expected to enhance aggregate quality as measured by the Los Angeles degradation test. Factor 3 may diminish aggregate quality.
\end{abstract}

\section{Introduction}

Pebble count data from Quaternary gravel deposits at 118 localities of the Front Range Urban Corridor north of Denver, Colo. (Fig. 1), were analyzed by multivariate statistical methods to assess relationships among rock types. The object of this analysis was to identify lithologic factors that might affect gravel quality (resistance to degradation) in aggregate applications. This report provides reference documentation for statistical analysis of gravel composition of the Front Range Urban Corridor and provides gravel pebble count data in electronic format.

\section{Data}

The pebble count data used in this study were taken from 101 localities posted on the map by Colton and Fitch (1974) and supplemented by data from 17 localities reported by the Front Range Infrastructure Resources Project (Fig. 1). Supplementary data from the South Platte River north of Denver (Lindsey and Shary, 1997; Lindsey and others, 1998) and the Cache la Poudre River (Langer and Lindsey, 1999) extend the region of coverage south and north of the data of Colton and Fitch (1974). The supplementary data also include unpublished data from four localities on Boulder Creek, the St. Vrain River, and the Big Thompson River. Table 1 contains pebble count data from all sources. 


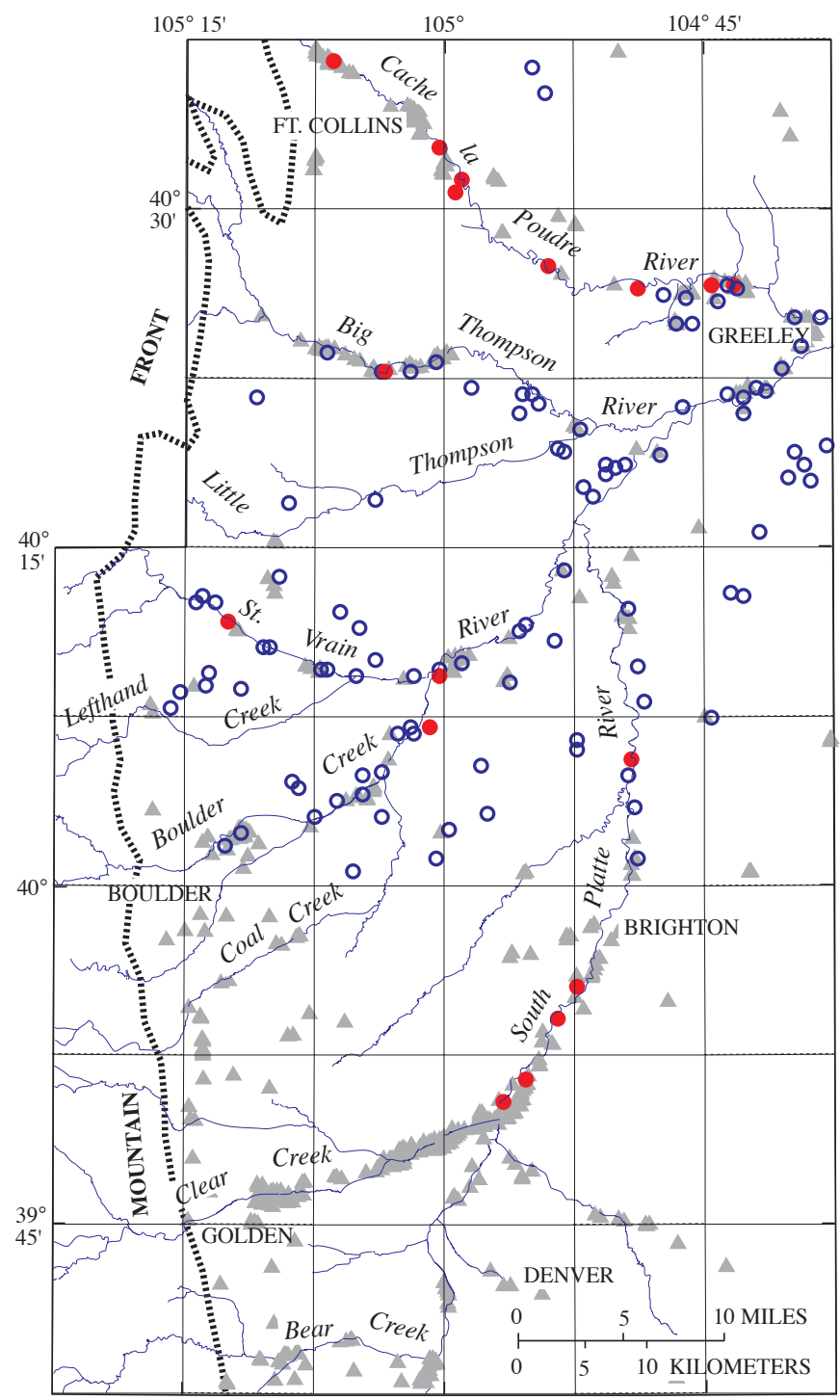

EXPLANATION

$\Delta \quad$ Gravel Pit (Hemborg, 1996)

Pebble Counts

- Colton and Fitch, 1974

101 localities

- Front Range Infrastructure Project 17 localities

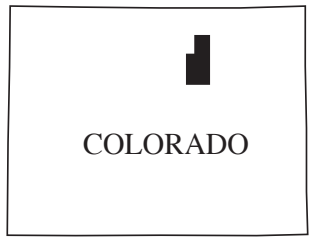

Figure 1. --Map showing gravel pits and localities for pebble count data in the Front Range Urban Corridor north of Denver, Colo.

Table 1.--Excel file of pebble counts, with sample locations, data sources, and classification of localities by terrace, gravel deposits of the Front Range Urban Corridor, Colo. Pebble counts in percent; quartz and metaquartzite reported as quartzite by Colton and Fitch (1974); counts that do not total 100 are left uncorrected because the reason for the discrepancy is unknown. Sample locations by Colorado well location system (Colton and Fitch, 1974) and UTM (Universal Transverse Mercator) coordinates. Terraces assigned from geologic map by Colton (1978). Nearest stream: B, Boulder Creek; BT, Big Thompson River; CLP, Cache la Poudre River; LT, Little Thompson River; SP, South Platte; SV, St. Vrain River; TMF, Table Mountain alluvial fan. Quaternary terrace 
deposits (youngest to oldest): Qpp, post-Piney Creek alluvium; Qpc, Piney Creek Alluvium; Qb, Broadway Alluvium; Qlo, Louviers Alluvium; Qs, Slocum Alluvium; Qv, Verdos Alluvium; Qrf, Rocky Flats Alluvium. Qc, colluvium. Download TABLE1.XLS or TABLE1.CSV.

A common problem in data analysis arises from combining data collected during different investigations, as was done for this study. Differences in data from different sources must be identified and their probable effect on data analysis must be evaluated. If the differences are judged too great, data from different sources cannot be combined. In the present study, data from Colton and Fitch (1974) differ from that of the Front Range Infrastructure Resources Project in counting method and sample type, clast size, and categories of rock types identified. Each of these differences is described, together with possible effects on data quality. For differences in categories of rock types, some types were combined to minimize any effect on data analysis.

Colton and Fitch's (1974) data are from 101 localities; each locality is represented by a count of 100 pebbles. The Infrastructure Project data are from 17 localities; each locality is represented by 2-9 counts of 50 pebbles per count and distributed according to various sampling plans. In general, such sampling plans produce greater precision in estimates of rock-type abundance than do single counts of 100 pebbles (see discussion of sampling plans by Miesch, 1976). For example, data from three localities on the South Platte River north of Denver represent averages of 50-pebble samples totaling 300-450 pebbles per locality, with each average representing the entire thickness of gravel (Lindsey and others, 1998). The principal effect of different sampling methods is variable precision. Pebble counts under the method of Colton and Fitch (1974) are likely to be less precise than those obtained by the Infrastructure Project. For the present (multivariate) analysis, variable precision (especially, low precision) may lower the magnitude of correlation among rock types and hinder interpretation.

The size of clasts counted by Colton and Fitch (1974) may differ from that by the Infrastructure Project, but any effect on the data is probably minor. Colton and Fitch (1974) report counts of "pebbles" without further specifying size of pebbles counted. All of the Infrastructure Project data are from pebble counts of the 0.75-1.5 or 2-inch size fraction--in other words, large pebble size. In the Wentworth (1922) scale of particle size, pebbles are 4-64 $\mathrm{mm}(0.15-2.5$ inches). It is not usually practical to identify very small pebbles and, when samples are not sieved, common counting practice includes clasts larger than pebbles. Colton and Fitch's (1974) data probably represent clasts of large pebble and greater size.

The rock types listed in Colton and Fitch's (1974) counts tend to be more specific, especially for igneous rocks, than those of the Infrastructure Resources Project. Colton and Fitch (1974) tabulated volcanic rocks separately as "rhyolite," "porphyry," "basalt," etc., whereas the Infrastructure Project tabulated volcanic rocks as "felsic, intermediate, or mafic porphyry." On the other hand, Colton and Fitch (1974) do not distinguish between vein quartz and quartzite; these rock types were recognized separately by the Infrastructure Project. Accordingly, in preparing the counts for statistical analysis, data were combined into broad categories such as "total volcanic rocks," "quartz plus quartzite," and "total sedimentary rocks" (Table 2). Most volcanic rocks in the project area consist of basalt, rhyolite, or a variety of intermediate composition, and most are 
porphyritic. Sandstone comprises most of the sedimentary rocks, but numerous minor types were identified. Mafic Precambrian rocks (mostly diabase and amphibolite) and schist were identified by both Colton and Fitch (1974) and the Infrastructure Project, but their abundance is not great enough at any locality to make them an important influence on aggregate quality. Thus, data on mafic igneous rocks and schist were not analyzed for this study.

Table 2.--Excel file of pebble count data prepared for statistical analysis, including combined rock types, row geometric means, and centered log-ratio data, gravel deposits of the Front Range Urban Corridor, Colo. Qz, vein quartz; Qzt, metaquartzite; VolcRx, total volcanic rocks; SedRx, total sedimentary rocks; RGM, row geometric mean. A value of 0.1 (not shown) was arbitrarily added to raw data values to permit calculation of geometric means and log ratios. Pct, percent. Download TABLE2.XLS or TABLE2.CSV.

\section{Statistical methods}

The multivariate statistical methods used here involve a combination of principal components and factor analysis. Principal components and factor analysis are described by Reyment and Savazzi (1999) and Cooley and Lohnes (1962), respectively. The following discussion summarizes the application of multivariate methods to pebble count data, using the method of log-contrast principal components analysis (method of Reyment and Savazzi, 1999), followed by rotation of principal components and factor interpretation. Steps in the analysis were:

1) Data preparation--Data for minor rock types were combined in the categories "total volcanic rocks" and "total sedimentary rocks" to assure the most stable values possible. A value of 0.1 was added to each data value to eliminate zero values for logarithm calculation and a centered log-ratio correlation matrix was calculated.

2) Principal components analysis--A principal components analysis was performed on a centered log-ratio correlation matrix with unities in the diagonal. The correlation matrix was solved for its latent roots (eigenvalues) and a new matrix specifying uncorrelated vectors (principal component axes) was calculated.

3) Selection of principal components--The first three principal components were selected for rotation, based on eigenvalues $>1$, inflection of the root curve, maximum communalities for log-ratios, and ease of interpretation.

4) Rotation of principal components--Principal component axes were rotated to new, orthogonal (uncorrelated) axes using the Kaiser Varimax criterion.

5) Factor interpretation--Rotated principal components were interpreted as geologic processes, based on factor loadings, and supported by knowledge of the physical properties and distribution of rock types in gravel.

The method of log-contrast principal components analysis (Reyment and Savazzi, 1999) was used to mitigate the problem of constant sums in the pebble count data. The sum of values in each row (pebble count) of the data matrix is 100 percent. This property, referred to as the "constant sum problem" (Chayes, 1960), constrains the values of 
correlation coefficients. Correlations are not free to range between -1 and +1 .

Correlations for major constituents are forced toward negative values. Moreover, when the number of constituents is reduced and recalculated to 100 percent, the correlations change. Although the method of log-contrast principal components analysis is the latest proposed solution for the constant sum problem, it may not be the final solution (Reyment and Savazzi, 1999).

The method involves calculating a new matrix of log ratios by dividing each data value in a row by the geometric mean of that row and converting the result to its logarithm (Table 2). A new covariance matrix, termed the "centered log-ratio covariance matrix," is calculated from the log-ratio matrix, and a corresponding centered log-ratio correlation matrix is computed (Table 3). The new correlation matrix is a measure of proportionality between the original rock types, represented by columns in the data matrix. Centered log-ratio correlation coefficients are not comparable to correlation coefficients calculated from raw data. Finally, in principal components analysis, the centered log-ratio correlation matrix is solved for its roots (eigenvalues--Table 4) and a new matrix of uncorrelated variables is defined (Table 5).

Selection of the number of principal components to preserve for rotation and factor interpretation is not always obvious. Criteria for selection are discussed by Jackson (1993). The number of principal components selected for rotation can be based on 1) eigenvalue magnitude greater than one, 2) the point on the eigenvalue distribution curve where an obvious change in magnitude occurs (root curve method), 3) eigenvalue distribution curve compared to eigenvalues calculated from random data (broken-stick distribution), 4) maximum communalities under various rotation scenarios, and 5) trial interpretation of rotated factors. Criteria (1), (2), (4) and (5) were used here.

Three principal components were selected for rotation and interpretation. The first three eigenvalues account for almost 77 percent of the total variance (Table 4) and the log-ratio communalities (Table 6) have a range of 0.634-0.932 (40-87 pct of total variance). The three rotated log-contrast principal components are: 1) granite and gneiss versus pegmatite, 2) quartz + quartzite versus total volcanic rocks, and 3) total sedimentary rocks versus granite (Table 7). For each component, the rock type with positive factor loadings is listed first.

\section{Interpretation and conclusions}

Interpretation of the principal components as factors is made from knowledge of the physical characteristics and distribution of each rock type in gravel (Table 8). Thus, factor 1 (grain size of igneous and metamorphic rocks) could represent destruction of pegmatite relative to granite and gneiss during weathering and transport. Owing to exposure of cleavage in large feldspar crystals, pegmatite might be expected to be weaker than granite and gneiss. However, pegmatite abundance tends to increase downstream whereas gneiss tends to decrease downstream. Granite shows both tendencies, depending on the stream. Relative abundance of granite and gneiss versus pegmatite in source terranes also may be reflected in factor 1; pegmatite tends to be abundant throughout the Cache la Poudre drainage. Factor 2 (resistant source rocks) represents the dispersion shadow of metaquartzite detritus, which may be overwhelmed locally by point sources of volcanic rocks or shallow intrusions east of the mountain front. Abundance of both quartzite and volcanic rocks may be enhanced also by resistance during weathering and 
transport. Factor 3 (proximity to sandstone source) represents dilution of gravel by soft sedimentary rocks (mainly sandstone), which are exposed in hogbacks near the mountain front. None of these explanations takes into account the possible effect of recycling old gravels, which may have had different sources and histories.

Factor 1 effects on aggregate quality are difficult to evaluate. Los Angeles (LA) degradation tests (Marek, 1991) of granite and pegmatite give variable values but are commonly in the same range as LA values for South Platte River gravel (Davenport and Langer, 1998; Lindsey and others, 1998). Test values for gneiss range widely but tend to be somewhat lower than those for granite, suggesting that abundant gneiss of sufficient hardness could improve aggregate quality.

Factors 2 and 3 should affect aggregate quality. Resistance to degradation, as measured by the Los Angeles (LA) test, should be enhanced by large amounts of quartz plus quartzite or by volcanic rocks (factor 2). LA tests of quartz reveal slightly better (lower) values than for gravel in the South Platte River (Lindsey and others, 1998; Davenport and Langer, 1998). Tests of quartzite are highly variable, but a test of Precambrian quartzite from Coal Creek Canyon, a major source of quartzite in Front Range gravels, gave an LA value somewhat lower than South Platte gravel (Davenport and Langer, 1998). Tests of volcanic rocks gave values much lower than South Platte gravel (Davenport and Langer, 1998). Resistance to degradation should decrease with concentration of soft sedimentary rocks (factor 3). LA tests of sandstone, which dominates pebbles of sedimentary rocks, show highly variable values that range from equal to much granter than those of South Platte gravel (Davenport and Langer, 1998).

\section{Acknowledgments}

The data collected by R. B. Colton and H. R. Fitch (1974) made this study possible. B. F. Arbogast, K. J. Ellefsen, D. H. Knepper, Jr., W. H. Langer, K. E. Livo, R. A. Melick, J. F. Shary and the author obtained lithologic data at four localities on Boulder Creek, the St. Vrain River, and the Big Thompson River. W. H. Langer, J. F. Shary and the author collected lithologic data on the South Platte and Cache la Poudre Rivers (Lindsey and Shary, 1997; Lindsey and others, 1998; Langer and Lindsey, 1999). C. S. Hiatt digitized sample locations and R. A. Melick converted the file of locations. 


\section{References Cited}

Chayes, F., 1960, On correlation between variables of constant sum: Journal of Geophysical Research, v. 65, no. 12, p. 4185-4193.

Colton, R. B., 1978, Geologic map of the Boulder-Fort Collins-Greeley area, Front Range Urban Corridor, Colorado: U. S. Geological Survey Miscellaneous Investigations Map I-855-G, scale 1:100,000.

Colton, R. B., and Fitch, H. R., 1974, Map showing potential sources of gravel and crushed-rock aggregate, in the Boulder-Fort Collins-Greeley area, Front Range Urban Corridor, Colorado: U. S. Geological Survey Miscellaneous Investigations Map I855-D, scale 1:100,000

Cooley, W. W., and Lohnes, P. R., 1962, Multivariate procedures for the behavioral sciences: New York, Wiley, 211 p.

Davenport, J. C., and Langer, W. H., 1998, Estimating Los Angeles degradation value using the Schmidt rebound hammer along the Front Range, Colorado: U.S. Geological Survey Open File Report 98-331, 38 p.

Jackson, D. A., 1993, Stopping rules in principal components analysis: a comparison of heuristical and statistical approaches: Ecology, v. 74, no. 8, p. 2204-2214.

Langer, W. H., and Lindsey, D. A., 1999, Preliminary deposit models for sand and gravel in the Cache la Poudre River valley: U.S. Geological Survey Open-File Report 99$587,27 \mathrm{p}$.

Lindsey, D. A., and Shary, J. F., 1997, Field measures of gravel in the South Platte River north of Denver, Colorado - A pilot study: U. S. Geological Survey Open-File Report 97-451, 19 p.

Lindsey, D. A., Langer, W. H., and Shary, J. F., 1998, Gravel deposits of the South Platte River valley north of Denver, Colorado, Part B - Quality of gravel deposits for aggregate: U. S. Geological Survey Open-File Report 98-148-B, 24 p.

Marek, C. R., 1991, Basic properties of aggregate, in Barksdale, R. D., ed., The aggregate handbook: National Stone Association, Washington, D. C., p. 3-1--3-81.

Miesch, A. T., 1976, Geochemical survey of Missouri--methods of sampling, laboratory analysis, and statistical reduction of data: U. S. Geological Survey Professional Paper 954-A, 39 p.

Reyment, R. A., and Savazzi, E., 1999, Aspects of multivariate statistical analysis in geology: Amsterdam, Elsevier, 285 p.

Wentworth, C. K., 1922, A scale of grade and class terms for clastic sediments: Journal of Geology, v. 30, no. 5, p. 377-392. 
Table 3.--Centered log-ratio correlation matrix, pebble count data, gravel deposits of the Front Range Urban Corridor, Colo. Qz, vein quartz; Qzt, quartzite; VolcRx, total volcanic rocks; SedRx, total sedimentary rocks; RGM, row geometric mean.

\begin{tabular}{|l|c|c|c|}
\hline Log ratio & Log (Granite/RGM) & Log $($ Gneiss/RGM) & Log (Pegmatite/RGM) \\
\hline Log $($ Granite/RGM) & 1.000 & .242 & -.513 \\
\hline Log $($ Gneiss/RGM $)$ & .242 & 1.000 & -.408 \\
\hline Log $($ Pegmatite/RGM) & -.513 & -.408 & 1.000 \\
\hline Log $((\mathrm{Qz}+Q z t) / R G M)$ & -.283 & -.178 & .017 \\
\hline Log $($ VolcRx/RGM $)$ & -.069 & -.282 & -.053 \\
\hline Log $($ SedRx/RGM $)$ & -.558 & -.110 & -.070 \\
\hline
\end{tabular}

\begin{tabular}{|l|c|c|c|}
\hline Log ratio & Log $((\mathbf{Q z + Q z t}) / \mathbf{R G M})$ & Log $($ VolcRx/RGM) & Log (SedRx/RGM) \\
\hline Log $($ Granite/RGM $)$ & -.283 & -.069 & -.558 \\
\hline Log $($ Gneiss/RGM $)$ & -.178 & -.282 & -.110 \\
\hline Log $($ Pegmatite/RGM) & .017 & -.053 & -.070 \\
\hline Log $(($ Qz+Qzt)/RGM $)$ & 1.000 & -.407 & .003 \\
\hline $\log ($ VolcRx/RGM $)$ & -.407 & 1.000 & -.249 \\
\hline $\log ($ SedRx/RGM $)$ & .003 & -.249 & 1.000 \\
\hline
\end{tabular}

Table 4.--Eigenvalues, log-contrast principal components analysis of pebble count data, gravel deposits of the Front Range Urban Corridor, Colo.

\begin{tabular}{|l|c|c|c|}
\hline Eigenvalue & Magnitude & Variance Proportion & Cumulative Variance Proportion \\
\hline 1 & 2.006 & 0.334 & 0.334 \\
\hline 2 & 1.497 & 0.250 & 0.584 \\
\hline 3 & 1.113 & 0.186 & 0.769 \\
\hline 4 & 0.805 & 0.134 & 0.903 \\
\hline 5 & 0.587 & 0.098 & 1.001 \\
\hline
\end{tabular}

Table 5.--Unrotated log-contrast principal components matrix, pebble count data, gravel deposits of the Front Range Urban Corridor, Colo. Qz, vein quartz; Qzt, quartzite; VolcRx, total volcanic rocks; SedRx, total sedimentary rocks; RGM, row geometric mean.

\begin{tabular}{|l|c|c|c|}
\hline Log ratio & Factor 1 & Factor loadings \\
\hline Log $($ Granite/RGM $)$ & .879 & .007 & Factor 3 \\
\hline Log $($ Gneiss/RGM $)$ & .580 & -.492 & -.257 \\
\hline $\log ($ Pegmatite/RGM $)$ & -.659 & .341 & .237 \\
\hline $\log (($ Qz+Qzt $) /$ RGM $)$ & -.407 & -.517 & -.316 \\
\hline $\log ($ VolcRx/RGM $)$ & .109 & .854 & -.578 \\
\hline $\log ($ SedRx/RGM $)$ & -.534 & -.377 & .229 \\
\hline
\end{tabular}


Table 6.--Communalities, log-contrast principal components analysis of pebble count data, gravel deposits of the Front Range Urban Corridor, Colo. Qz, vein quartz; Qzt, quartzite; VolcRx, total volcanic rocks; SedRx, total sedimentary rocks; RGM, row geometric mean.

\begin{tabular}{|l|c|}
\hline Log ratio & Communality \\
\hline Log $($ Granite/RGM $)$ & .839 \\
\hline Log $($ Gneiss/RGM $)$ & .634 \\
\hline Log $($ Pegmatite/RGM $)$ & .651 \\
\hline Log $(($ Qz+Qzt $) / R G M)$ & .767 \\
\hline $\log ($ VolcRx/RGM $)$ & .793 \\
\hline Log $($ SedRx/RGM $)$ & .932 \\
\hline
\end{tabular}

Table 7.--Orthogonal factor loadings, Varimax rotation, log-contrast principal components analysis, gravel deposits of the Front Range Urban Corridor, Colo. Qz, vein quartz; Qzt, quartzite; VolcRx, total volcanic rocks; SedRx, total sedimentary rocks; $\mathrm{RGM}$, row geometric mean; bold type, factor loadings $>10.501$.

\begin{tabular}{|l|c|c|c|}
\hline Log ratio & Factor 1 & Factor loadings \\
\hline Log $($ Granite/RGM $)$ & $\mathbf{5 5 2}$ & -.104 & Factor 3 \\
\hline Log $($ Gneiss/RGM $)$ & $\mathbf{. 7 9 0}$ & .099 & $\mathbf{- . 7 2 4}$ \\
\hline $\log ($ Pegmatite/RGM $)$ & $\mathbf{. 8 0 0}$ & .085 & -.027 \\
\hline $\log (($ Qz+Qzt)/RGM $)$ & -.255 & $\mathbf{. 8 3 7}$ & .063 \\
\hline $\log ($ VolcRx/RGM $)$ & -.285 & $\mathbf{- . 8 2 9}$ & -.022 \\
\hline $\log ($ SedRx/RGM $)$ & .083 & .052 & -.157 \\
\hline
\end{tabular}

Table 8.--Factor interpretation, log-contrast principal components analysis, gravel deposits of the Front Range Urban Corridor, Colo.

Factor 1--Granite and gneiss versus pegmatite (grain size of igneous and metamorphic rocks, reflects degree of destruction during weathering and transport and/or relative proportion of rock types in source terrane). Effect on Los Angeles degradation values and aggregate quality unknown.

Factor 2--Quartz + quartzite versus total volcanic rocks (resistant source rocks, reflects dispersion of mostly metaquartzite detritus, with possible additional concentration by weathering and transport). Should decrease Los Angeles degradation values, thus increasing aggregate quality.

Factor 3--Total sedimentary rocks versus granite (proximity to sandstone source, reflects dilution of gravel, mostly by sandstone from hogbacks). Should increase Los Angeles degradation values, thus decreasing aggregate quality. 